Chapter Two

\title{
BIOGRAPHICAL EPIPHANIES IN THE CONTEXT OF LAYING THE FOUNDATIONS OF THE QUALITATIVE THOUGHT COLLECTIVE
}

\author{
by Marcin Kafar
}

\section{Introduction}

In May 2006, the University of Illinois held the Second International Congress of Qualitative Inquiry conference. One part of the congress was a panel moderated by Carolyn Ellis, perhaps the most prominent promoter of the autoethnographic trend in the contemporary humanities. She invited to the meeting several leading figures involved in the qualitative research methodology, including Norman K. Denzin, Yvonna S. Lincoln, Laurel Richardson, and Arthur P. Bochner. These researchers, supported by Ronald J. Pelias and Janice M. Morse, made an attempt to portray the context of the creation of a thought collective, tied around the qualitative thought style. ${ }^{1}$ The palette of issues streamlining the individual statements (presented in the form of several-minute flashback stories) mostly fluctuated around the lives of individual researchers, from whom they learned the qualitative approach, which events conditioned their location in such and no other point of the scientific scene, and finally, where on this scene they situated themselves.

The narrated stories (contained in one of the chapters of the book Ethical Futures in Qualitative Research) ${ }^{2}$ bring closer the political and institutional

1 The concepts of 'thought collective' and 'thought style' I use in the senses given to them by Ludwik Fleck (1979 [1935]).

2 Coda: Talking and Thinking about Qualitative Research (Ellis et al., 2007). 
background of qualitative thinking patterns; the imagination is also moved by-complementary to the layers describing the outer conditions of the creation of the qualitative thought collective-these planes of the stories, in which we find direct references to the experience that is personal, sometimes intimate, to the breakthroughs and decisions following them, both 'professional' and 'private'-purely human.

The existence of these shades of biographical stories, which is clearly shown by the accounts referred to in the subsequent paragraphs of this chapter, suggests that without the individual experience (and the specific type of self-reflection built on it), it probably would not be possible to constitute the field of qualitative research in the form in which we know it today; this conclusion leads in turn to a wider question about the role of the personal dimension in the context of creating scientific worlds.

Years ago, Ludwik Fleck (2007a; 1986a; 1979 [1935]), followed by Thomas Kuhn (1977; 1996), clearly and convincingly exposed the social nature of the construction of scientific knowledge. At the same time, the same authors, eagerly supported by masses of commentators of their work, effectively assured us in our belief in the fact that what allows knowledge to take on an expressive and relatively permanent form (thought style, paradigm), is the close dependence on certain group activities. Knowledge gains legitimacy circling within the web of intersubjective relations; it is a sine qua non condition for practicing science at all. While not acting against this in a sense unquestionable principle (extreme individualism is essentially non-discoursive), it is worth while to think to what extent, within what scope, and with the mobilization of what resources an individual actually participates in the process of building collective consciousness.

This trail arises somehow involuntarily when we start to cope with the confidences of Denzin and Lincoln, and, for some reasons, first of all, with the considerations of Bochner, Ellis and Richardson. What is collective, what aspires to be a turning point in the community dimension, to constitute, as it would be put by Fleck, a "form" ${ }^{3}$ that organizes the collective,

3 In Fleck's theory of thought styles and facts, the word 'form' is one of the most important words. It is a metaphor embracing the distinctive features of some collective: objects of observation and ideas related to them. "We look with our own eyes, we see with the eyes of a collective body," Fleck (1986b [1947], p. 134) used to say. Drawing on the findings of psychology he described form as follows: "[...] every perception is, in the first place, a seeing of some wholes, while the elements are only seen later. Sometimes these elements may remain unknown. We recognize at first sight a man of our acquaintance or a known flower, but often we are completely unable to give the distinguishing features accurately. We see all at once that somebody has a sad look, though we do not know which detail of his facial features changed. We see that the general appearance of a room has changed, but we do not know which item of furniture have been moved. Moreover, 
grows from the soil of life's dramas-the death of the loved ones, accident, serious illness, accompanying others in suffering, contact with the evil deepen the old and raise the new doubts, symbolically activating in the researcher-human the desire to radically rethink the attitude towards the world in its various forms, and in different revelations: theoretical, empirical, experiential, emotional, relational, creative, and that reflected by all the others, forming me as a person and being a value in itself. ${ }^{4}$

It is understandable that practicing science deposited on such basis, they had to adopt separate, characteristic for them criteria for the delimitation of cognitive research boundaries, objectives, methods, and techniques for-to use the old language-collecting empirical data; they also dared to develop peculiar interpretation tools and methods for their use; and finally, they made the effort of systematic work on the contemporary vocabulary and rules for its use, oscillating towards writing corresponding to the needs of the times of change (the subject of language will be referred to a little more fully below).

The effect of these actions was cementing the platform, whose construction was initiated by a group that originally was quite scattered, and then more and more consolidated, as they used to talk about themselves. It was a group of scientific outsiders, individuals perceiving the reality differently than those inclined to maintain the status quo representing the mainstreams of the social sciences and humanities. This revolution could happen due to the favorable "spirit of the times' and "liminal personae" feeling it.

in spite of many different details we can observe an identical form within a specific whole, a specific 'entirety'; thus all Chinese people may seem to be identical to the eye of a European, although undoubtedly they have individual differences. The word 'father' when pronounced by the squeaky voice of a child and by the drunkard's bass of a sailor may have not a single sound in common, but it is still the same word. It is precisely such entireties, which trust themselves upon sensory perception, and which are to a large extent independent of constituent elements, that psychology calls 'forms', regardless of the sense which supplies them. Thus we can have visual forms, e.g. a certain tune, a word; or olfactory ones, e.g. the smell of grocers' shops, or of railway stations" (ibid., pp. 130-131)].

4 I base this idea on the writings by a Polish philosopher Józef Tischner, discussing in his works on dialogue the notion of 'axiological I' (see e.g. Tischner, 2005; 2006a; Tischner \& Kłoczowski, 2001). The associations between Tischner's ideas and the qualitative thought style perspective in autoethnographic manifestation are described in O przetomie autoetnograficznym w humanistyce (On Autoethnographic Shift in the Humanities) (Kafar, 2010), which, in its thematic content, is strongly intertwined with the text presented here.

5 Expression borrowed from Victor Turner (1978). 


\section{Biographical Epiphanies}

\section{Story I-Norman Denzin and the 'Skipped Line'}

"By the end of the 1970s, I had hit a brick wall and other walls as well. I had taken symbolic interaction about as far as I thought it could take me. And I was profoundly dissatisfied with the wall the perspective had hit. That is, it had become closed off from all sorts of other discourses that I was being exposed to on this campus in criticism and interpretative theory, which was an interdisciplinary program in the humanities. ${ }^{6}$ So by the late '70s, we were reading European social theory that was just being translated. Lacan, Heidegger, Foucault, the feminisms, and we were moving into semiotics. It was a three-year project of being saturated with theory that sociology was excluding.

About this time, we formed a traveling minstrel show and some of the members are on this panel: Carolyn, Laurel, myself, and Patricia Clough. We would go to the symbolic interactionist annual meetings and do postmodern performances, and we would get booed and hissed. One of the more profound moments was when Laurel presented the life of Louisa May, ${ }^{7}$ the poetic representation of an interview transcript. She later published this as 'The Skipped Line' (Richardson, 1993). The room was like this, packed, and Laurel had distributed her transcript of this interview, which she then proceeded to poetically perform for us. I think it was Harvey Farberman, a symbolic interactionist, who raised his hand and said, 'You skipped a line, and therefore, the validity of what you are doing is at question. You are not being true to her life and to her words.' That skipped line provoked a give and take in the journals and opened this space that we were in, a space of skipped lines, and it was okay to be there. Even if our colleagues didn't like it, that was the space we were going to be in. So then for several years, we did this kind of traveling road show and confronted a fair amount of hostility. But as we did, I think the momentum started to build behind us" (Ellis et al., 2007, p. 240).

\section{Story II-Yvonna Lincoln and an Encounter with Evil}

"I want to talk about an epiphany and an ethical crisis at once. But before I do it, you should know that I lived a sheltered childhood. I grew

6 Denzin describes a situation that occurred at the University of Illinois (footnote-M.K.).

7 The total of the phrases in bold in this section is intended to provide a kind of an overtext, a tale within the tale that keep a dialogue with each other and complement each other to form a whole. 
up in a very traditional family. My brothers ran wild. I was locked in the house for thirty-two years. So I didn't have much experience with a lot of stuff, and my epiphany came when I was out on an evaluation contract. I was very new. I had had my doctorate for about a year and I was doing this evaluation contract and trying to be a good qualitative naturalistic evaluator. I began to suspect that in this project, the middle school coach was molesting some of the boys on one of his teams. And I didn't know what to do about that. That was before we knew very much about laws that said you had to report stuff. I went to the superintendent and said, 'I don't have any hard evidence, but there is a bunch of kids who are telling me things and I think you need to do something about it.' Once the young boys were questioned, it turned out to be true. I thought all qualitative researchers were all good and that they encountered only other good people in the world.

My epiphany was finding out there really is evil in the world; there really are hideous things that happen to kids that never should. I have to tell you that that came as an epiphany to me because it was the first time I realized that. I know that really sounds stupid-see this is one of the things that doesn't go in, right?-but this was the first time in my life that I felt that I had come face to face with what I geminately would describe as evil rather than bad or rude or discourteous or un-Christian. It was evil, just evil. I was very young; I don't think I was but thirty-one years old. It was quite frightening, and that was an epiphany for me" (ibid., pp. 240-241).

\section{Story III-Laurel Richardson, Coma and Split 'I'}

"I love the word epiphany. Every part of your mouth gets going: e-piph-any. Marvelous word. And I think Norm is the one who's introduced it into our living research vocabulary. I want to quickly talk about two of my epiphanies.

I've always been a qualitative/quantitative researcher-what is now call mixed methods. I find them kind of fun. Mixed-up methods. But I had a major car accident and I was in a coma for some while and I when I came out of that coma, I was not able to do my fourth-grade mathematics. That was a life-changing epiphany. I lived through that, but my mind was pretty scrambled up. My first paper was a power analysis of Paradise Lost (Milton, [1667] 2003). I hadn't read Paradise Lost since college. I didn't even know I knew it, but I did. Things were scrambled up, but I wanted to continue being an academic. My department didn't want to tenure me because I might be brain damaged (little did they know what was yet to come). At that time, feminism was growing but there was no structured 
way of teaching students about gender issues. I was a feminist, so I decided to write a textbook, The Dynamics of Sex and Gender (Richardson, 1977). Some of you may have read it. Writing that book introduced a new field and helped establish it as one that did not require knowledge of statistics to make sense of the world. That is, it established gender studies, women's studies, and sociology of women as fields of knowledge accessible to everybody. People without advanced mathematics. And through the writing, I retaught myself the bases of sociological reasoning. Writing for my life, writing so I would have a life. ${ }^{8}$ That was the first epiphany.

The second epiphany was having a book contract on unwed mothers and finding myself unable to write. I was frozen. The crisis of representation had truly hit me. I didn't know how to write. For whom do I write? Whose life can I write? What do I say? At the same time, I was experiencing the tension between two sides of myself: the scientist and the poet. I wanted to feel more integrated. How was I going to put myself together?

I ended up writing a life-history interview of the unwed mother, 'Louisa May,' as a narrative poem and presenting it a sociology conference. This experience-along with talking with others who were also involved with writing themselves out of the crisis of representation-created the space in the discipline and in our world where we could be a community. People who were interested in altering qualitative methods, who recognized poststructural thinking, postpostmodernist critique, feminism, queer theory, and so on, could now have a space in which to create community. The experience of performing Louisa May at an ASA convention, where people swore at me and accused me of fabricating my research, led to my involvement with others who had their epiphanies in the same space" (Ellis et al., 2007, pp. 242-243).

Story IV-Arthur Bochner, the Death of His Father and Meeting Carolyn Ellis

“Before I read Norm Denzin's book (1989), which focused on epiphanies, I didn't know what an epiphany was. Now I see them everywhere. In 1988, my father died suddenly of a heart attack. I was at an academic conference, a National Communication Association convention in New Orleans. And my world was shaken by that experience. I wrote about that in a story I call 'Narrative and the Divided Self' (Bochner, 1997). My father's death exposed to me the cleavage of my experience as a human being and as an academic. I had always struggled with this distance between the personal and the academic. I realized after my father's death that my days were numbered, and it was time to stand up and do what my heart said was important.

8 More information on these issues can be found in e.g. Getting Personal (Richardson, 2001). 
At the time, I was in somewhat enviable position of being the chair of the USF Communication Department and I felt it my calling, I guess, to develop a new Ph.D. program that very much embodied what Laurel just said about a sociology without quantities. I never believed that communication was the stuff of quantities to begin with. At that time, in 1990, we had the opportunity of developing this program that everyone in my discipline and even many in my home university said would never work. But I was firm in my conviction that there were people out there, especially woman, Third World people, and indigenous populations, who were yearning for such an opportunity.

I also had a serendipitous meeting with Carolyn Ellis in 1990. I attended a lecture she gave in, of all places, the business school, and as I heard her give a short narrative taken from her book, Final Negotiations (Ellis, 1995), I said to myself, 'She's giving my talk. There's someone else out there in another discipline who believes all the things I believe.' That, as they say, was the beginning of a beautiful friendship and the start of our project on ethnographic alternatives" (Ellis et al., 2007, pp. 243-244).

\section{Story V-Carolyn Ellis, Life Soaked with Loss and Finding 'the Other I'9}

"My first epiphany occurred when my brother Rex died in 1982 in an airplane crash on his way to visit me. My world was turned upside down, and I think this was the only time in my life I would define myself as depressed. Not only had my brother died but my partner, Gene Weinstein, was entering the final stages of a chronic disease. The survey study on jealousy I was doing seemed insignificant and I craved to explore and try to understand what I was feeling-to get myself out of the depths of despair. That was the beginning of my turn to autoethnography, to exploring and writing about myself and my situation to learn about human behavior. Finally, I was able to connect my love for social psychology with my love for engaged qualitative methods.

My second epiphany came with the death of my partner, Gene Weinstein and the responses I got to my writing Final Negotiations about relationship and his dying. I felt the narrative story I was writing was the best sociology I had ever done, and to get the varied responses I received was mind-opening and mind-boggling: 'This isn't sociology or research,' 'This threatens the whole sociological enterprise,' and so on. All of it made me more determined to make my case that this was sociology.

9 "For Art, my other I," this is the dedication put by C. Ellis in her programmatic book, The Ethnographic I: A Methodological Novel about Autoethnography (2004). 
Norman's response to a paper I did on introspection ${ }^{10}$-that I was being schizophrenic-helped me move from trying to fit into a mainstream sociological model to finding my own place on the margins, one that connected humanities and social science and advocated for an emotional sociology that cared about people.

My third epiphany occurred when I met Art Bochner and found a like-minded colleague and partner. Together we created a synergistic relationship and ethnographic project, and we were able to do more together to advance an interpretive and humanistic social science than either of us could have done alone" (ibid., pp. 244-245).

\section{On Understanding the Meaning of Epiphany}

The readers of the stories presented above received a clear indication for interpretation-that is the word 'epiphany,' and more specifically, the meaning layer of that word. The intention of Carolyn Ellis preparing the thematic structure of the panel was to treat epiphany as a 'headword,' designed to refresh the memory of the congress participants. This solution was the result of inspiration derived, as suggested by Richardson and Bochner, directly from the thoughts of Norman Denzin. Therefore, it is worth, I think, bringing the latter closer, treating them as a prelude to further discussion.

The author of Interpretive Interactionism harnessed the concept of epiphany for biographical analyses, highlighting the conscious participation of human subjects in the social world. We focus here on persons experiencing moments of crisis, interpreted-through incorporating them into the plot of biographical and autobiographical stories of life transforming moments-as turning point experiences. The flagship exemplum of such turning point crisis is the life of Martin Luther King. On January 27, 1956, the activist fighting for the rights of African-Americans received threatening phone calls. Later, not being able to sleep, he kept sitting at an empty kitchen table and wondered about what lay ahead. At one point, lost in the depths of despair, he heard-as he claimed-the voice of Jesus ensuring him that he will never leave Martin: "I could hear an inner voice saying to me, 'Martin Luther, stand up for righteousness. Stand up for justice. Stand up for truth. And lo I will be with you, even until the end of the world.' ... I heard the voice of Jesus saying still to fight on. He promised never to leave me, never to leave me alone. No never alone. No never alone. He promised never to leave me, never to leave me alone," says King. This scene is recalled, inter alia, in the book, Bearing the Cross by David Garrow (2004, p. 58),

10

Cf. Ellis (1991). 
which strongly stresses its transformative nature. The biographer of the future Nobel Prize winner notes that "the vision in the kitchen" repeatedly became a reference point for King, especially when the burden he carried seemed too heavy for him (cf. ibid., p. 89, 123, 171, 412).

Denzin willingly uses the example of Martin Luther's biography, introducing the reader into the context of his own understanding of epiphany. Perhaps this is because the casus of King allows him to make a relatively smooth transition between the source semantic plane, pointing to the illumination $^{11}$ as a specific form of establishing the relation between God and man (the chosen person), and a revelation not having a clear religious connotation. Social researcher is interested not so much in capturing the experience limited to the sphere of what is felt, generally speaking, in the purely spiritual dimension, but rather in the separation of the principle (and using it as an interpretation trick) of the 'discovery' of what had previously remained 'overshadowed.' Perhaps this is why, in my opinion, the term 'epiphany' first used in Interpretive Interactionism is provided with a quotation mark (Denzin, 1989, p. 15), and as an additional support-making the intentions of the hermeneutist more precise-there emerges James Joyce with his Dubliners (ibid., pp. 16-17), a text which serves as a field for experimenting with the original theory of epiphany.

The touch of Joyce is really well suited within the contour of the interpretive approach developed by Norman Denzin, since, in fact-it is my additional stance-he needs 'new' clothes for the 'old' experience; the genius of the creator of Ulysses is proving to be invaluable in this regard, which seems to be confirmed by the expert in Joyce, i.e. Tomasz Gornat. In his erudite work, "A Chemistry of Stars": Epiphany, Openness and Ambiguity in the Works of James Joyce (2006), he looks for the foundations of the theory of epiphany in the utterances of Stephen Dedalus, who, as we know, is Joyce's literary disguise. In Stephen Hero, Dedalus defines epiphany as "a sudden spiritual manifestation, whether in the vulgarity of speech or of gesture or in a memorable chase of the mind itself" (Joyce, 1963, p. 211). Such 'spiritual raptures'-leaving Joyce aside for a moment-belong to the two spheres, corresponding to the heterogeneous nature of epiphany: first, in

11 Epiphany was originally rooted in the Greek cultural context, which well reflects the language and its use (epipháneia means a 'revelation' from epiphainein-'to show,' 'to reveal' (source: Wielki..., 2010, entry: epiphany)). In ancient Greece, epiphany exclusively meant literal illumination. Gods and goddesses descending to Earth and interacting with mortals were described by the then contemporary literature (such as the Iliad, Odyssey and less well-known texts, such as the Apollo Epiphanies by Istrus). In biblical terms, epiphany (and theophany) embraces all situations in the world of the divine revelation in the world of man (cf. Langkammer, 1990, p. 53). Also, the Christian feast celebrated on January 6 is known as the Epiphany. 
the case of consciousness focused on religious feelings, man directly experiences things that bear the hallmarks of divinity (theophany); and second, in the case of awareness facing towards sensations deprived of the divine element, we deal with illumination, equipping us with the brand new 'vision' of things, flashing in the previously unknown light tone ${ }^{12}$ (secular epiphany) (cf. Gornat, 2006, pp. 23-24). Joyce's Stephen reveals to his interlocutor that the clock on the Ballast Office may also cause an epiphany: "I will pass it time after time, allude to it, catch a glimpse of it. It is only an item in the catalogue of Dublin's street furniture. Then all at once I see it and I know at once what it is: epiphany" (Joyce, 1963, p. 211). Epiphanies are Virginia Woolf's "little miracles," her "matches struck unexpectedly in the dark" (Woolf, 1960, p. 249), Conrad's "moments of awakening and vision" (Conrad, 1921, pp. vii-xii), Hemingway's "moments of truth" (cf. Beja, 1971, pp. 49-52) and Eliot's "timeless moments in time" (cf. Nichols, 1987, pp. 190-198).

\section{Attributes of Epiphanic Experiences}

The distinction between the divine insights into the earthly world of people from secular illuminations is helpful both in organizing Denzin's ideas and making exegesis of the stories that I am most interested in, of scientific transformations and their sources. At least at the first glance, the stories of Lincoln, Bochner, Richardson, Ellis and Denzin, have distinguishing features allowing to locate them on the side of secular epiphanies. To give the reader a closer hint of what I mean, I will refer to (based on the definition of epiphany of Morris Beja, ${ }^{13}$ tracking theophanies and illuminations in modern literature) three categories, or rather principles that make up a kind of idiom of epiphanicity, in terms of: (i) incongruity, (ii) suddenness ${ }^{14}$ and

12 I am playing with the meanings of the source word; epiphainein can be translated as 'to reveal' or 'to light up.'

13 The definition I refer to describes epiphany as "a sudden spiritual manifestation, whether from some object, scene, event, or memorable chase of the mind-the manifestation being out of proportion to the significance or strictly logical relevance of whatever produces it" (Beja, 1971, p. 18). This definition, as can easily be noticed, largely coincides with Joyce's definition put into the mouth of Stephen Dedalus; it complements the latter adding to it the rule of disproportionality. To read more on the comparison of the definitions coined by Beja and Joyce see Gornat (2006, p. 26).

14 I'm talking about the 'suddenness' for the lack of a better word, plastic enough to fully embrace the specificities of epiphanic experience in its initial point. When we are on the border of the Words and Non-Words dimensions, it seems most appropriate to think-again I follow Józef Tischner-“from within the metaphor" (Tischner, 2006c, p. 240); epiphany is an 'instantaneous flash of fire,' 'first ray of light falling into the cave,' these "matches struck unexpectedly in the dark" (Woolf). 
(iii) spirituality, all of which are written into an epiphany and determine its specific character. The descriptions, which I will refer to in a while, embrace each of these rules. What are the consequences that result from it?

\section{Suddenness}

"One of the more profound moments was when Laurel presented the life of Louisa May, the poetic representation of an interview transcript," Denzin-narrator says, recalling at the same time an assessing statement of Harvey Farberman ("You skipped a line, and therefore, the validity of what you are doing is at question.") and concluding: "That skipped line provoked a give and take in the journals and opened this space that we were in, a space of skipped lines, and it was okay to be there." Farberman's voice acts like a surgical scalpel, in a split of a second dividing the reality and causing mutual surprise. His casual remark reveals that there is no ' $u s^{\prime}$ ', but there is 'we' and 'they'-the classic symbolic interactionists and belonging to the 'other' (mental) space-qualitative arguers. Is it really so that a "space of skipped lines" did not exist before Laurel described the life of Louisa May? Or maybe the gap was just too narrow to squeeze through it?

"[...] my epiphany came when I was out on an evaluation contract," confesses Yvonna Lincoln, and reveals that the evil, which she knew little of, suddenly took on a concrete form, and what was worse, it was discovered in a person that was supposed to be an educational model figure ("I began to suspect that in this project, the middle school coach was molesting some of the boys on one of his teams"); suspicions prove to be true, evil emerges from the shadows to display another face of the world in front of the narrator.

"I had a major car accident and I was in a coma for some while," recollects Laurel Richardson, adding that when she recovered she "was not able to do [her] fourth-grade mathematics." Life soaked with extreme experience seeks the return of the fitting existential framework; the narrator feels that with every hurt tissue of the body, concluding: "[...] through the writing, I retaught myself the bases of sociological reasoning. Writing for my life, writing so I would have a life. That was [...] epiphany."

Another epiphany of Richardson nourishes itself on the word 'stillness' ("I didn't know how to write. For whom do I write? Whose life can I write? What do I say?"), which throws a bright beam of light on the identity crossroads ("At the same time, I was experiencing the tension between two sides of myself: the scientist and the poet"). 
The news of the unexpected death of his father put Arthur Bochner at the junction in the world, ${ }^{15}$ from where the ends of the horizon are clearly seen ("my days were numbered").

His "serendipitous meeting with Carolyn Ellis" is the epiphany effecting in, as it would be put by Józef Tischner, a significant shift in the interhuman contact (Tischner, 2006b, p. 19) ("I [...] had a serendipitous meeting with Carolyn Ellis in 1990. [...] That [...] was the beginning of a beautiful friendship and the start of our project on ethnographic alternatives").

"My first epiphany occurred when my brother Rex died in 1982 in an airplane crash on his way to visit me. My world was turned upside down," Ellis confides. The emptiness suffered by her is still deepened by the death of Gene Weinstein, and now the loss is already so overwhelming that it makes it impossible to remain in the same place, it is not surprising, therefore, that a subtle suggestion coming from the outside, irrevocably changes the course of events: "My second epiphany came with the death of my partner, Gene Weinstein and the responses I got to my writing [...] about relationship and his dying. [...] to get the varied responses I received was mind-opening and mind-boggling: 'This isn't sociology or research,' 'This threatens the whole sociological enterprise,' and so on. All of it made me more determined to make my case that this was sociology. Norman's response to a paper I did on introspection-that I was being schizophrenic-helped me move from trying to fit into a mainstream sociological model to finding my own place on the margins."

\section{Incongruity}

Situation, scene, gesture, fraction of a conversation, etc. are epiphanic when suddenly and seemingly without reason they gain a 'surplus of meaning'; they appear to be something more than they should. Ellis and Bochner's meeting is not just one of a number of meetings on the stage of academic theatrum mundi; it gains the importance of an Event. ${ }^{16}$ Bochner addresses, but also-literally and figuratively-is addressed. ${ }^{17}$ His question induces

15 The phrase 'junction in the world' was created by Józef Tischner (2006c).

16 “To meet means more than to be aware that the other is present next to me or nearby me. Immersed in the street crowd, I am aware that there are other people nearby me, but that does not mean that I meet them. A meeting is an event," says the philosopher of dialogue (Tischner, 2006c, p. 19).

17 The meeting-event is mentioned by Bochner and Ellis on a number of occasions presenting it in various forms, in Ellis's Revision, this private-public story is presented as follows: "Art: Who is this woman anyway? How could we have been on the same campus for the last six years and never met? Of course, the truth is I was immediately attracted to her 
Her answer, and vice versa-Her question is immediately followed by His response, making them The Others for each other. ${ }^{18}$

WhileFarberman treats the remark of the skipped linein a purely polemical dimension (as an argument supporting the position vested in the discussion), Denzin immediately sees the'difference' in it that constitutes separate scientific communities.

Lincoln, discovering child abuse committed by a teacher, moves the problem from the realm of legal responsibility into the area of morality; she also sees in it a clear indication for her own explorations reaching ethical foundations of life and work.

Severe disease in Richardson is not limited to somatic losses and injuries carving deep furrows in the psyche; coma, in this case, is a call to open the windows when the door gets locked,19 it becomes, as it would be put by Arthur Frank, a call for remoralization. ${ }^{20}$ Disease, as confirmed by the casus of Richardson, is a threat that turned into an opportunity (cf. Frank, 2002, pp. 1-7).

passion and energy (to say nothing of her good looks). She seems to be about the same age as me, give or take a few years, and her talk focused on how she had taken care of a partner who died. I couldn't help wondering: Is she available? Unattached? If she is, is she still mourning her loss? Hmmm, I liked her vitality and sense of humor. I thought I ought to at least give it a shot, go up and meet her, feel out the possibilities. So I waited until the crowd around her dissipated and introduced myself. We walked out of the room and into the parking together. Carolyn: After talking, we decided to exchange articles we'd published. On Monday, I had a student run some things across campus to Art's mailbox. That day and the next, every time I went to my mailbox, I had another article from Art. Sometimes only an hour apart. Hm, I thought, this is definitely an academic form of flirtation. So I wrote Art a note thanking him for the articles, and added, 'I'm certainly glad we found each other'" (Ellis, 2009, p. 112; form as in the original).

A beautiful passage about 'The Other' can be found in Ślad i obecność (Trace and Presence) by Barbara Skarga (2002, p. 53), where she writes, "There is an experience in which the whole of our being is focused in one moment, as if through a lens, that very moment makes a rare experience, but one who felt it, knows what it means. Here invades my being the other, who is suddenly met. We meet others all the time, but this one is not in a crowd, he is in front of me, face to face, and at that moment my multi-ecstatic time freezes. The other [...] brings shock, imbalance that has no past behind it and has not opened for the future yet. He shakes me with his presence. I can defend against this otherness, try to reject it, and finally forget it. But the moment of this presence has already changed the course of my life, marked a profound turning point in my existence. The presence of the other may become precious or unbearable. Meeting the oppressor is just as shocking as meeting the lover. And these meetings weave the thread of our lives, marking the moments of presence in our timing."

19 "When God closes a window, she opens a door"-it is the final sentence of At the Will of the Body, by Arthur Frank (2002, p. 156).

20 "Once the body has known death, it never lives the same again," says Frank in At the Will of the Body (p. 16), and elsewhere he writes, "Illness and disability call upon people to become morally engaged because they have everything to lose, but also to gain" (Frank, 2004, p. 177). 
Creative (writing) impotence is seen as an identity-based category and not a transitional state of mind.

Finally, the moments when one's beloved leave them (in the case of Bochner, Ellis) go beyond the personal tragedy (combined with a deep human need to experience grief), being converted into the necessity of performing an axiological volt.

\section{'Spirituality'}

Epiphany is inseparable from transcendence (Latin: transcendere-'to cross'), but depending on the 'ideological base' creating the 'perspective' of our reading out the epiphanic experience, it fits either into the absolute being (God) versus the limited being (human) relationship, or is exhausted in the plan of man versus the external object, ${ }^{21}$ the first situation corresponds to theophany, the second-to the secular epiphany. In both cases, the act of 'crossing' refers to reaching 'beyond' the material realm. It is, to look for a visualizing expression, an 'opening up' to such or another non-ordinariness (Stephen-Joyce explains Cranly in his further considerations on the clock: "Imagine my glimpses at that clock as the gropings of a spirituals eye which seeks to adjust its vision to an exact focus. The moment the focus is reached the object is epiphanised" (Joyce, 1963, p. 211)). The 'spiritual' attribute of epiphany is also linked to its timelessness; epiphany is a 'point,' which means that it shows its strength by throwing a person into a 'momentary void'; in epiphany there already is no past, and the future has not yet arrived; epiphany is 'eternal now.' The meaning of epiphanic eternity now recalls the principle of void by Laozi. "Thirty spokes join the wheel nave/ And make of void and form a pair,/ And a wagon's put to use./ Clay is thrown to shape a vase/ And make of void and form a pair,/ And vessel's put to use./ Door and window vent a room/ And make of void and form a pair,/ And a room is put to use," says the sage (Laozi, 2004, p. 51). Emptiness therefore determines the usefulness of what can fill it in, but what is more-it promotes the launch of source potency, it is a gap, that line skipped by Richardson; thanks to it, almost everything is possible, or at least what was un-think-able is now realized ("That skipped line provoked a give and take in the journals and opened this space that we were in, a space of skipped lines (Denzin)); ("I ended up writing a life-history interview of the unwed mother, 'Louisa May,' [...]. This experience $[. .$.$] created the space in the discipline and in our world$ where we could be a community" (Richardson)). A fleeting moment of

21 To read more on understanding transcendence cf. Wciórka (1994, p. 381). 
epiphany is defined by its capacious ovary, its modality, subjunctivity (in the sense coined by Turner (cf. Turner, 1995)), combined with the almost unlimited suitability to the tilt 'towards the new.'

\section{Epiphany and 'Biographical Landmarks'}

Each border experience, and epiphany belongs to that category, is first a presence in itself to use the vocabulary of Barbara Skarga. The suddenness of epiphany, the transcendental nature moves towards the 'raw' being, but-this is very important (!)-is not exhaustive in such being; the 'naked sensation,' as I would put it, is covered by the awareness of it, and this in turn brings to the fore reflexivity. "The moment of reflection," says the philosopher, "and this presence already pulls away and distance is created, even a minimal one" (Skarga, 2002, p. 51), ${ }^{22}$ the distance facilitating assessing the gravity of the sensation and its irreplaceability. Epiphany, to remain within the spirit of the impressions of Kwintet metafizyczny (Metaphysical Quintet), is "my own experience, not for sale or exchange with others, the original experience, from which I draw and that wakes me up, triggering my rise from being submerged in the world, wakes me up to what is [...] my project of being, and if not a project, my own vision of myself and of what surrounds me, the experience confirming something that is, and maybe should be the essence of my existence" (Skarga, 2005, p. 128).

When we highlight this background, it appears advisable to look at epiphany from the perspective-as would proceed Norman Denzin-revealing in it the aspect of 'biographical landmark.' Epiphany acts then as an indelible marker; it defines the line dividing life into 'before' and 'after' or 'then' and 'now,' favoring the reflection of who I am, who I was and who I should be. Epiphany, under certain conditions, appears to be a turning point, because it "wakes up something in me, asks something of me, leads me in a new direction, cancels my previous desires and goals. As if somewhere in the depths of my self a transformation was carried out, sometimes only partial, but already significant, sometimes crucial, penetrating the very fabric of my identity" (ibid., pp. 127-128). Man experiencing a revelation-illumination is someone whose awareness is significantly transformed, in whom a feeling is converted into certainty, or, on the contrary, what was certain, like under a magic spell, becomes immediately questionable, and therefore, requiring retouching.

22 I will track once more the Joyce's interpretation of epiphany, to find-following Dedalus-"the first quality of beauty," which however is sometimes subjected to meticulous judgment. "Beauty," says Stephen, "is declared in a simple sudden synthesis of the faculty which apprehends. What then? Analysis then" (Joyce, 1963, p. 212). 
The autobiographical stories of Bochner, Richardson, Ellis and other scientific converts are the visible signs of changes situated between the 'living experience' and the intensive work of consciousness imposed on it, which seeks to turn life upside down almost entirely; in terms of producing new quality and applying it for the purpose of the forming of my ' $\mathrm{I}$ ' and the world behind it. "If experience has the narrative quality attributed to it here, not only our self-identity but the empirical and moral cosmos in which we are conscious of living is implicit in our multidimensional story. It therefore becomes evident that a conversion or a social revolution that actually transforms consciousness requires a traumatic change in a man's story. The stories within which he has awakened to consciousness must be undermined, and in the identification of his personal story through a new story both the drama of his experience and his style of action must be reoriented. Conversion is reawakening, a second awaking of consciousness. His style must change steps, he must dance to a new rhythm," writes Stephen Crites (2001, p. 43).

At this point, there is a convergence of the views of Crites and the thought of Józef Tischner, situating the issue of consciousness transformation at the junction of the inner and outer world of man. "Transformations of consciousness are an internal reflection of the external human drama," says the author of Etyka solidarności (Ethics of Solidarity) (Tischner, 2006c, p. 242, see also, Tischner, 1978), basing his argument on the principle of solidarity and egotic de-solidarity; according to it, ' $\mathrm{I}$ ' can strive in two directions. When ' $\mathrm{I}$ ' gets entangled around some 'axis values,' it shows some kind of solidarity with itself, and when it removes the value from the field of view, it ceases to be true to itself (Tischner, 2006c, p. 242). But what exactly does it mean to be true to oneself?

Fidelity to oneself-to reach for yet another Tishner's idea albeit close to the discussed one-is a constant man's search for his proper ethos, and through it an attempt to reach the essential existential ground, leading me and You to the good that builds us. If a human "discovers where, among which issues, with what kind of people h i s ethos is linked, he may 'bear abundant fruit.' If he does not find it, he will live as an alien creature to himself," firmly states the philosopher from Polish Highlands (Tischner, 2006a, pp. 171-172; spelling consistent with the original). His passages on the ways to ethical recognition encourage to looking for such layer-explicitly localized, and who knows, maybe key from the perspective of narratorsof the stories about 'scientific' and 'personal' conversions. ${ }^{23}$

23 Conversion (Hebrew: $\hat{s} u b$, Greek: epistrephein-change of the way, return, turning back from the way, Greek: metanoia-internal conversion), usually associated with the area of religious experience, also has its equivalent in the form of a laic experience, which is understood as "a transition in the inner life to higher degree of excellence"; in this 
The theme of seeking personal ethos is most clearly evident in the stories told by Ellis and Bochner; they, in my opinion, in a unique way experience the 'desire' to bear witness on what they experienced. The word 'desire' is attributed here the metaphysical color in the sense presented by Emmanuel Lévinas. "To feel the desire is not the same as to feel the need. The need is always associated with a 'saturation' with this, to which it turns. Intentionality of the need is two-way: the need for food turns to bread, eating bread is the 'satiating' of nutritional values of bread. A similar kind of 'satiating' occurs in the case of looking, listening, many intellectual acts. Anyone who feels the need, also vaguely sees what could satisfy it. [...]

It is different in case of Desire. 'Metaphysical desire,' writes Lévinas, seeks something entirely different, something absolute in its Otherness. Satisfying the desire does not satisfy any hunger, because it reaches those who already satisfied their hungers. The desireis 'unhappiness of the happy.' Even love cannot fall into the category of desire, as it is the hunger and saturation. Desire is more like human kindness and actions arising out of goodness do not saturate goodness, but deepen it further. Anyone who has been good, desires to be good. And so in the desire: what is desired does not fill in the desire, but hollows it even more" (Tischner, 2006b, p. 71, see also, Tischner, 2006c, pp. 28-37).

"There Are Survivors," Carolyn gave that title to her story about Rex's death (cf. Ellis, 1993). This phrase heard on the radio, waking a vain, as soon appeared, hope, included in the told story becomes particularly significant. Ellis turns to those who participated in the flight and actually survived the crash, but also to those who, like her, still live even though they have suffered irreparable losses. While grieving she discovers that in order to make the suffering tolerable, she needs to start talking about it. She talks and writes for herself, while thinking about others; her desire is to draft a map giving the people who suffer (whoever they are) some clues in the chaos of blurred experience, she desires to give evidence that would indicate that life, after all, is more valuable than death.

The autoetnography There Are Survivors was printed in 1993, two years before the publication of Final Negotiations. Interestingly, the events depicted in the two narratives took place more than a decade earlier. Rex died in 1982, and Gene Weinstein a few months afterwards. I mention this fact considering that silence which lasted for more than a decade is too meaningful to remain interpretively indifferent to it. How then should we understand these ten years of silence?

sense we talk about the "second conversion," evoking-according to the term by Jan Pryszmont (1994, p. 293) -“"new personal attitude." 
Well, in my opinion, this period of silence is rooted in the bipartite ground-purely personal, not to say-intimate and professional, associated with the need to develop a vocabulary suitable for the utilization by the scientific collective. Still, it seems that there is a point at which the highlighted areas converge and overlap.

Sometimes, extreme and traumatic experiences clothe us in silence; I fall silent when the pain is beyond me, when it becomes too great for me to be able to express it, articulate it. This regularity for a long time prevented the Jewish Holocaust survivors from returning to the drama of the war not only in their own memory, but also in verbal recollections (see e.g. Frankl, 1959); the language loses its power also in the face of severe disease (vide the case of Laurel Richardson); then the function of speech, of course not directly, is taken over by the body. "Seriously ill people are wounded not just in body but in voice. [...] in the silences between words, the tissues speak" (Frank, 1995, p. xii) (pain forcing to scream?); after all, the context of the disease in general, not necessarily of chronic or terminal nature, works to the disadvantage of 'speaking,' at least at the level of the colloquial use of language. Suffering and pain ruthlessly expose any linguistic non-excellences, which was vividly recognized once by Virginia Woolf (1930, p. 11): “English, which can express the thoughts of Hamlet and the tragedy of Lear, has no words for the shiver and the headache. It has all grown one way. The merest schoolgirl, when she falls in love, has Shakespeare or Keats to speak her mind for her; but let a sufferer try to describe a pain in his head to a doctor and language at once runs dry. There is nothing ready made for him. He is forced to coin words himself, and, taking his pain in one hand, and a lump of pure sound in the other (as perhaps the people of Babel did in the beginning), so to crush them together that a brand new word in the end drops out."

The new word of Virginia Woolf falls within, if treated as a metaphor, the area of Ellis's efforts to find her own voice (i.e.: the reconstruction of the ' $\mathrm{I}^{\prime}$ ), which-let me condense the course of events-eventually turned out to be a joint voice of the "wounded storyteller" (Frank, 1995) and a sensitive engaged social researcher involved. What did the various stages of reaching this point look like?

Ellis launches from confronting the traumatic experience with the quite rational element, seeing in the therapeutic dimension of writing an Ariadne's thread-a thread capable of leading her out of the labyrinth of the crisis: "I'm just going to sit here and write about what is going on in my life because I'm unable to get through this any other way.' I started to write and was amazed at how writing organized my thoughts and helped me set them aside and move on to what had to be done next. The process was 
rationally therapeutic" (Holman Jones, 2004, §48; form as in the original). In other places we read: "Writing has served to put all the 'little incidents' into a bigger picture of recognizable patterns that contradicts to some extent the sense of 'disorientation and disintegration' that threatened me when I lived this story. These patterns give the impression, quite groundless, of control and rationality, which as [Nancy] Mairs says, 'may save one's sanity even though it can't save one's own or anyone else's life'" (Ellis, 1995, p. 328). ${ }^{24}$ "I couldn't stop writing because [...] [writing] might help me and others understand and cope with loss provided day-to-day meaning and continuity. Sometimes I felt I was lighting to make my work meaningful in order to rekindle the deeper meanings of my life-a life now superficially safe, afloat in a rowboat, yet threatened by a sea of continuously challenging waves of response no matter where I placed my oars. In which direction would I go? Or did the strength and unpredictability of the waves make direction a mute concern? Finally, I pulled in my oars and set off on my own adventure, eager to see where it would lead me" (ibid., p. 309).

I have suggested above that Ellis's long silence was due not only to the attempts to cope with the loss as such (personal-intimate dimension of experience), but also the loss which, as directly confirmed by the statements of the author of Final Negotiations (cf. ibid., pp. 303-337), in its intention, from some point aspired to take the form of research-ethnographic/ sociological work. The trouble was, however, that neither Carolyn nor anyone from the group of people working with her had the right vocabulary suitable for use in the description of the border experiences without also ripping them off very subtle senses. This problem will become a bit clearer if we approach it from the metalevel of considerations of Ludwik Fleck and, closer to our time, Richard Rorty.

On the occasion of a polemic with a psychiatrist and philosopher of medicine, Tadeusz Bilikiewicz, Fleck says, "It seems that it is less important to consider all ideas and theories, such as embryonic evolution of the

24 Ellis's confession is similar to what Laurel Richardson (2001, p. 33) felt: "After the car accident and coma, I could not find simple words much less remember proper names, dates, titles of papers or journals, or perform statistical tests fourth-grade arithmetic. Although I could not bring into speech what was happening in my head, I found that I could write about it. If I could not find the word I wanted, I could write its first letter or leave a blank space. In writing, the space and the issues were my own, not the maddening questioning of others. Writing allowed me to record little thoughts, to revisit them and fill in the blanks, to piece them together, thought-by-thought. Writing gave me a feeling of control over time and space, and a faith that I would recover. Writing was a method through which I constituted the world and reconstituted myself. Writing became my principle tool through which I learned about my self and the world. I wrote so I would have a life. Writing was and is how I come to know" (italics in the original). 
eighteenth century, than to carry out an analysis of individual texts, like an analysis of an unknown code. Picturing the content of the view from a past epoch with contemporary expressions is impossible, because the individual terms of this era are incomparable to the present ones. The 'embryo' of the views of the eighteenth century is something very different than the 'embryo' of today's style of embryology. [...] The stylish aura of concepts has changed, and the views change accordingly. Now, we must first examine the aura of concepts, their stylish color, reflecting in the language custom regarding the use of certain words, particularly their metaphorical use. Only this opens the door to studying the thought style of the epoch" (Fleck, 2007b, p. 268; italics in the original).

Such revealing feelings of Fleck find support in the findings of Rorty congenial with them. The author of Consequences of Pragmatism notes that "scientific breakthroughs are not so much a matter of deciding which of various alternative hypotheses are true, but of finding the right jargon in which to frame hypotheses in the first place" (Rorty, 1982, p. 241). Scientific jargon appears here not as a means by which we are going to describe reality as it really is, but as a means of responding to local, instantaneous demand for given social worlds. There is no 'universal vocabulary of science,' but there are numerous 'particular vocabularies,' "jargons" generating an opportunity of "coping with things"; such a pragmatic approach assumes, in the case of the constitution of any new stream of research (and related to it scientific moral community; the thought collective), that each time there is a need to "hunt for new terminology" and use "casting about for a vocabulary," inventing 'adequate' concepts and containers for them, or their forms of expression. "Vocabularies are useful or useless, good or bad, helpful or misleading, sensitive or coarse, and so on; but they are not 'more objective' or 'less objective' nor more or less 'scientific'" (ibid., p. 203), writes the philosopher of hope. This finding is all the more important since it allows the author to lead us to-equally radical and logicalconsequences expressed as follows: "if we get rid of traditional notions of 'objectivity' and 'scientific method' we shall be able to see the social sciences as continuous with literature-as interpreting other people to us, and thus enlarging and deepening our sense of community. [...] The lines between novels, newspaper articles, and sociological research get blurred" (ibid.).

Rorty, following his custom, carries the findings regarding the languages of science onto the level of social sciences to distinguish between two basic current trends in contemporary vocabulary: first, in terms of "descriptions of situations which facilitate their prediction and control," and second, in terms of "descriptions which help one decide what to do" 
(ibid., p. 197). The dictionary of predicting and control is the 'dictionary of politics'; the dictionary supporting decision-making is the 'dictionary of ethics.' I reach for these distinctions, because they allow me to recreate briefly (and thus with some simplification) the trail, followed by Carolyn Ellis and her kin from the qualitative thought collective.

The work 'before the turning point,' established on the basis of initial fieldwork held among fishermen in the Chesapeake Bay, is described by its author in the following words: "My dissertation was organized around 'legitimate' sociological topics-social structure, family, work, and social change. Within this framework, I discussed 'hard' sociological concepts, such as personal attachment, locus of social control, reciprocity, public conformity, civic status, individualism, communitarianism, center, and periphery. Yet, it was difficult to capture the complexity of the lives of the fisher folk using these categories, and I often felt unsure of the distinctions I was forced to make. To me, these theoretical concepts seemed as vague, subjective, and ethereal as emotional experience. I wish now that I had placed more emphasis on how people felt, which was my primary interest" (Ellis, 1995, p. 6).

Through the last sentence Carolyn clearly shows her preference for choosing the dictionary of ethics, since, instead of turning her face towards the stage (Tischner (2006c, p. 7) would call it the "attitude of intentional objectivity"), she directs it towards man; going in for acting between us. "I also wish now that I had been more present in my writing about the fishing communities. Mostly, I describe 'them,' the fisher folk, interacting with each other, as though I am off in the corner, invisible. In reality, most of what I learned came through my interactions with the people, especially their reactions to me. [...] I anguished over speaking in the first person, having been told it was 'unprofessional' and that readers would then conclude I had not been neutral and distant" (Ellis, 1995, p. 6).

Accents postulating the presence of me-researcher with them-the presence that should be updated by an ethnographic/sociological text-appear in the final stage of the consciousness work coming after 'the turning point' experiences and are associated with a strong imperative of soaking social sciences with humanistic element in general. This is not to be an individualized path, followed by a single wanderer-conquistador. On the contrary-Ellis with all her strengths wishes to create a "collective project that seeks to humanize sociology, create a space for experimental texts, and encourage writing stories that have meaning and make difference in people's lives" (ibid., p. 336). That project began in a place of dramatic existential pain, and then was transferred into a public place, occupied by a man sunk-as Lévinas would say-in poverty, someone earnestly 
seeking his axis mundi. In preparing the original version of Final Negotiations, the author feels great dilemmas: "I knew I did not want to write a traditional academic book and that I wanted to write a book that would speak therapeutically to a mass audience and sociologically to an academic one. But, I feared there were too many stories to tell to too many people [...]. What kind of book would I write? Would I tell my story, or use it as grist for sociological analysis? Would it be a scholarly or trade book? Would I write to social scientists or a mass audience? If social scientists, would it be all sociologists or some sympathetic section of them, such as symbolic interactionists, those to whom I had addressed my papers? Would it be a self-help book or a contribution to the sociological literature?

These issues arose as I was going through intense grief. The losses of Gene (1985) and my brother (1982) were renewed when first my dog of fourteen years died (1986), and then my father passed away (1987). Any questioning reaction to my work presented more threat of loss-loss of identity-and I often felt defensive and judgmental in response to criticism. Similar to irresolvable grief that often results from ambiguous feelings felt toward a loved one who dies, negative criticism coupled with indications that my work was important made it more difficult for me to resolve how to accomplish this project" (ibid., pp. 308-309). Ellis's struggles are not wasted, they are forged into a "discourse [that] connects human experience as live to research on emotions and intimate bonds, permitting my 'heart and head [to] go hand and hand.' [...] As this discourse becomes a part of sociological perspective, my life and work are coming together in meaningful ways. The result is a sociology that connects life experience to the pursuit of knowledge. This view makes the activity of doing sociology personally meaningful [it is intertwined with the personal ethos-M.K.] and anticipates for sociology what [Victor] Turner once said about anthropology, that it can become 'something more than cognitive game played in our heads and inscribed in-let's face it— somewhat tedious journals'"] (ibid., p. 335; bold added by M.K.).

\section{$\cos$}

"I must take charge of my life/story" (ibid., p. 333), categorically rules Carolyn Ellis, clearly defining in this way the direction of her new path. Arthur Bochner faces a similar challenge; on the day of his father's death he enters a border situation and this always requires from a man posing critical questions. As Józef Tischner (2006a, pp. 186-187) says, "In the ‘border situation' a man always brushes against the 'border' of his human existence. At that point, we either lose ourselves or recover oneselves. Because each time, 
we build and destroy something in us. A man shows his true nature in the 'border situation.'

The basic example of a 'border situation' is experiencing responsibility. I am what I am. I am responsible for myself. Mine is the merit, mine is the fault. I have the courage to look into my own interior and accept myself without any dodging.

An important hallmark of a person is the ability to take responsibility. Nothing demonstrates better the maturity of a human being. Man was thrown into the world both real and ideal, and is responsible for the extent to which these two worlds meet each other."

The author of It's About Time, upon his father's death, experiences a collision of two worlds-the world of hard science, which he previously dabbled in and the world of mundane, tangible human feelings assuming deep meaning after what had happened. Bochner knows (or only dimly anticipates) that the choice he makes will determine his future life. He can lose himself, he can save himself...

"I felt dazed and confused, like a boxer startled by the first powerful blow from a stronger opponent. Stunned by the punch, he hears competing voices, one inside his head whispering, 'Ignore the pain, stay with the game plan,' the other calling from the site of his body's pain and injury, rejecting the authority of consciousness over bodily experience.

A voice inside my head said, 'Get home to Tampa as quickly as possible. Mother will need you. She'll expect you to take control, help arrange the funeral, and keep the family from falling apart.' Suddenly, the three papers I was to present at the convention had little significance. However, I was too responsible to miss sessions without forewarning. I should contact the chair of each program, get someone to substitute if possible, give other participants to prepare for my absence.

But a second voice kept intruding on my own thoughts. I felt dizzy and lightheaded, as if I were teetering on the edge of a dangerous cliff. As I wiped away the tears trickling down my face and felt the flood of anxiety swirling through my stomach, I was terrified to realize that I couldn't shut down what I was feeling by an act of willful control. My father's death was not just another event to be organized, experienced, and filed away. It wasn't only my plans for the weekend that had been interrupted, but something much bigger" (Bochner, 1997, p. 419).

When Art-overwhelmed with the absoluteness of the experience-is not strong enough to lift up the phone receiver and tell his friends about the situation, something unexpected happens, there appear signs of great inner transformation that carries heavy consequences both for Bochnerman and Bochner-scientist: "As I sat in the corner and watched Herb 
organizing my affairs, I recalled the times I had tried to talk to him about interest on death and dying. These conversations never got very far. Herb resisted invitations to delve deeper and I usually felt disappointed that we couldn't connect on this topic. Now, I was beginning to understand why these conversations have been so frustrating and superficial. At the time, Herb's parents were dead; mine were alive. For Herb, death had been personalized, for me, it was academic. Under these circumstances, what did we really have to talk about? How could we possibly speak the same language? As a result of my father's death, I had passed into another dimension, one that was missing when Herb and I had tried previously to converse about death. We still weren't talking about death or loss, but when Herb looked at me from across the room, I felt the kind of communion that can only occur when two people are woven into the same fabric of experience.

On that long plane ride home, I realized as never before that I was a human being. It sounds strange to say that, I know, but I believe it is true. My father's sudden death forced me to grasp the significance of how contingent, limited, and relative human experience can be. Most of us realize that fear of death lingers behind the absorbing details of our everyday lives, but we keep our fear sedated because we sense it could infect us if we let go. When our lives are interrupted by the reality of death, our immunity is weakened. Then, if we allow it, we can drop the canopy of dishonesty covering the brute fact that we don't really control our lives. [...]

My father's death made it possible, even necessary, for me to see the consequences of splitting the academic self from the personal self in a new light. At my university, or at conferences, I normally move in and out of analytical or conceptual frames without experiencing anything akin to an experiential shock or epiphany. But when my father died while I was attending a national communication convention, two worlds within me collided, and I was stunned to learn how tame the academic world is in comparison to the wilderness of lived experience. [...]

Now, the academic man in me stood face-to-face with the ordinary man. What did they have to say to each other? Could they get in touch with each other? Integrate? Harmonize?" (ibid., pp. 420-421; bold in the original).

The confession of Arthur Bochner, expressed in the form of an internal dialogue, largely directed towards himself, imperceptibly turns into a call and challenge, ${ }^{25}$ gaining Tischner's spirit of working on exploring and discovering ethos: "My personal struggle after my father's death was 
not a scientific crisis but a moral one," says Art and adds, "and the moral questions that were raised cast a long shadow over both my personal and my academic lives. I needed to take measure of my own life and of my father's too. How were the different parts of my life connected? What values shaped the life I wanted to live? Why would my academic life be if I could bring those values into play? What would it feel like?" (ibid., 423). Running away from objectivism, within which (no matter what the reasons were) Bochner operated before, after the traumatic events he goes on a journey with a one-way ticket: referring to, inter alia, the views of Stanley Milgram, Thomas S. Kuhn, Ronald D. Laing, Keneth J. Gergen, and first and foremost Richard Rorty that are like drops of water hollowing out the rock called the scientistic image of the world, he demands from himself a radical change of the ideological optics from one mounted on a quest to learn to one involving the desire to act justly; hence there arises the postulate regarding the need to move away from the pure scientific theory, to implement something that Art gives the name of social theory. While the first is a weave of abstract concepts and terms, considered to be aloof to life and free from values, the second assumes as its goal vivid participation in building a reality based on the idea of social and communication activity: "In the world of social theory, we are less concerned about representation and more concerned about communication. We give up the illusions of transcendental observation in favor of the possibilities of dialogue and collaboration. Social theory works the spaces between history and destiny. The social world is understood as a world of connection, contact, and relationship. It also is a world where consequences, values, politics, and moral dilemmas are abundant and central" (ibid., p. 435).

\section{Conclusion}

Finally, I propose to draw attention to the issue, which will serve as a buckle closing the output of my thoughts. Emile Cioran in his book, Tears and Saints, ventured to say that "All conversions are sudden but they take years germinating underground. [...] Divine revelations break out after a long period of incubation" (Cioran, 2003, p. 96). Please, remember, Dear Reader, Stephen's dialogue with Cranly... Ballast Office clock, seen every day by Dedalus hiking in the streets of Dublin, once finally becomes an epiphany; but... before it happened... many gestures were made (Stephen: "I will pass it time after time, allude to it, catch a glimpse of it"), constituting "the gropings of a spirituals eye which seeks to adjust its vision to an exact focus. The moment the focus is reached the object is epiphanised" (Joyce, 1963, p. 211). 
Therefore: epiphany is not hung in a void, not always and not everywhere.

"Mocking my fears and hopes, flashbacks of live TV footage of passengers from my brother's plane floundering in the Potomac River were interrupted in real life by Gene choking and yelling for me to untangle his oxygen hose. Suddenly, the scientifically respectable survey of jealousy I was working on seemed insignificant. Instead, I wanted to understand and cope with the intense emotion I felt about the sudden loss of my brother and the excruciating pain I experienced as Gene deteriorated," says Carolyn Ellis (1995, p. 8), poignantly describing the moment of experiencing the awareness change. It was not, however, as it turns out, a radical change founded on the ashes of the old world, but rather a bold, full opening of the already repealed door. In the Introduction to Final Negotiations (entitled Beginning), there are micro-stories approximating the academic life meanders of the researcher 'before the transformation.' The narrator presents there herself as a character thoroughly ambivalent, torn between the desire to meet the serious scientific challenges (requiring adherence to the rigor of objectivism and distancing oneself emotionally from the subject of study) and pursuing close relationships with people. The very first fieldwork, i.e. the one carried out in the Chesapeake Bay, evoke in the researcher a feeling of identity contradiction, deepening day by day: "I often experienced conflict between remaining uninvolved and distant, as I had been trained, and participating fully; between recording only my 'objective' observations of fisher folks' actions and speech and noting my sense of their emotional lives, a process that required my engagement. Often distance won out over involvement because of my concern about meeting the requirements I had learned for being a neutral social scientist.

When I returned to the university to write my dissertation, I struggled with the constraints of detached social-science prose and the demand to write in an authoritative and uninvolved voice. Though I worked hard to follow these principles, professors I admired still reprimanded me for having 'gone native' and for being too sympathetic toward my subjects" (ibid., p. 6).

In the following paragraphs, Carolyn writes, "Even during this research, however, I was drawn to stories for conveying lived experience and insisted on inserting vignettes showing specific incidents. In these stories, I could occasionally be present, though I rarely got to speak and almost never got to feel. But I knew, even then, that I wanted readers to hear the participants' voices and see them acting. The vignettes breathed life into my more passive telling and categorizing of the fisher folk" (ibid., p. 7). 
Seen in this context Ellis's epiphany seems to crown a specific stage of the struggle of the ' $I$ ' in order to become a leaven of their next revelation; it is therefore a unique point, however inscribing itself in a very wide arc of life.

Similar motifs, if not identical in their meaning in relation to those tracked in the story of Ellis, can be found in the biographies of Bochner and Richardson and in texts corresponding with them. The father's death induced the author of It's About Time to make a bold move, but was it the real beginning of the transformation? In September 2010, during my internship at the Department of Communication at the University of South Florida (the alma mater university of Bochner and Ellis), I asked Art about the beginnings of his interest in qualitative methodology. To my surprise, he did not mention his father's death, but at once referred to other tragic events. He told me about the mental illness of his first wife and trying to cope with that situation, and also about the thoughts aroused in him by reading books; first, in 1974, Pathway to Madness by Jules Henry (1965), and later Robert Coles's The Call of Stories (1989).

What is extremely intriguing is also the background against which Laurel puts herself: "I'm sitting here and deciding whether to start my qualitative experience at my birth. I think the fact I've been a marginal person with a foot in two different culture ${ }^{26}$ from my birth on did construct me as a sociologist and later as a qualitative researcher. It's a gift. I've been fortunate to be born into two different cultures. What moved me forward was the capstone course I took as an undergraduate at the University of Chicago. That course was called The Organization, Methods, and Principles of the Sciences. In that course, we dealt with intuitive work, deductive work, induction, reduction; and it wasn't like there was only one way to do science. Rather, there were multiple ways by which you might come to know something" (Ellis et. al., 2007, p. 236; form as in the original).

At the beginning of my article I suggested that a qualitative revolution would not have happened but for the emergence of liminal individuals, fitting the 'spirit of the times.' It is an appropriate time for a brief development of this thought.

In Dramas, Fields, and Metaphors, a collection of essays explaining and exemplifying the theory of 'societal change,' its founder, Victor Turner, pointed out the outstanding function played in the process of innovative cultural change by "conscious human agents" (cf. Turner, 1978, pp. 16-17; italics in the original). These "threshold thinkers" with a non-conformist attitude towards the ambient world, "the unacknowledged legislators of mankind," seeing farther, harder and deeper than others, "prophets"- 
these names are used by the eminent anthropologist (ibid., p. 28)-have a tendency to cross rigid conventions, to test the valid standards and rules in order to focus on making maximum use of "the powers that slumber within man." "In liminality," says Turner, "resides the germ not only of religious askesis, discipline, and mysticism, but also of philosophy, and pure science" (ibid., p. 242; form as in the original). Both tasks are completed by those who became 'men apart' belonging-by their own choice, or an external indication-to the social, existential and mental (imaginary) border zones marginal, and peripheral to the areas-it is necessary to add-that enable those residing in them perception of the reality in the perspective unattainable for people colonizing cultural centers. To the group of "liminal thinkers," Turner includes, inter alia, those feeling the spirit of change, post-renaissance writers, artists and philosophers (ibid., p. 28), and I do not hesitate to place beside them the creators of the qualitative thought collective. I was encouraged to make such a move, coincidentally, by Ludwik Fleck [sic!], carefully, not to say-liminally read Ludwik Fleck. Revealing the backstage of scientific discoveries, the author of Genesis and Development of a Scientific Fact writes that they are carried out by the appearance of intellectual excitement and tendency to change in the era of a balance that gave rise to "a chaos of contradictory, alternate pictures. The picture, fixed up now, disintegrates into blots which arrange themselves into different, contradictory shapes. From other fields, previously separated or neglected, some motives are added; historic connections, almost accidental, various intellectual relics, often also the so-called errors, mistakes and misunderstandings for their part add other motives. At this creative moment there becomes embodied in one or more investigators the mental past and present of the given thought-collective. All physical and mental fathers are with them, all friends and enemies. Each of these factors pulls to its side, pushes or inhabits. Hence the flickering chaos. It depends on the intensity of feeling of the investigator whether the fact, whether the new shape will appear to him within the chaos as a symbolic vivid vision, or else as a weak hint of a resistance which inhabits the free, almost discretional choice between alternate pictures" (Fleck, 1986c [1935], pp. 76-77; bold added by M.K.).

The pattern of the emergence process of a 'form' serving as the operator of a given thought collective, perfectly fits the atmosphere penetrating the stories of Denzin, Richardson, Bochner and Ellis. Their performances, provocative speeches, suffering insults from orthodox scholars, general anxiety of the research soul, strenuous search for new inspirations meant to provide the theoretical and methodological points of reference, and finally creation of their own language tools that allow for the construction 
of the dictionary congruent with our beliefs, is nothing else but Fleck's chaos, causing mood tension among the group of converts, or-as Turner would rather call it-a liminal state, desired by conscious human subjects that have chosen to follow their path.

Is there, in the midst of all that I have mentioned above, also the place for epiphanic experiences and transformations of consciousness lurking behind them? The unconvinced are asked to be patient.

\section{References}

Beja, M. (1971). Epiphany in the Modern Novel. Seattle: University of Washington Press.

Bochner, A.P. (1997). It's About Time: Narrative and the Divided Self. Qualitative Inquiry, 3, 418-438.

Cioran, E.M. (1995). Tears and Saints. (I. Zarifopol-Johnston, Trans.). Chicago: University of Chicago Press.

Conrad, J. (1921). Preface. In J. Conrad, The Nigger of the Narcissus: The Works of Joseph Conrad (pp. vii-xiii). London: William Heinemann.

Coles, R. (1989). The Call of Stories: Teaching and the Moral Imagination. Boston: Princeton University Press.

Crites, S. (2001). The Narrative Quality of Experience. In L.P. Hinchnam \& S.K. Hinchnam (Eds.), Memory, Identity, Community: The Idea of Narrative in the Human Sciences (pp. 26-50). Albany: Suny Press.

Czermińska, M. (2000). Autobiograficzny trójkąt: Świadectwo, wyznanie, wyzwanie. Kraków: Towarzystwo Autorów i Wydawców Prac Naukowych Universitas.

Ellis, C. (2009). Revision: Autoethnographic Reflections on Life and Work. Walnut Creek: Left Coast Press.

Ellis, C. (2004). The Ethnographic I: A Methodological Novel about Autoethnography. Walnut Creek: AltaMira Press.

Ellis, C. (1995). Final Negotiations: A Story of Love, Loss, and Chronic Illness: Philadelphia: Tample University Press.

Ellis, C. (1993). "There Are Survivors": Telling a Story of Sudden Death. Sociological Quarterly, 34, 711-730.

Ellis, C. (1991). Sociological Introspection and Emotional Experience. Symbolic Interaction, 14, 23-50. 
Ellis, C., Bochner, A.P., Denzin, N.K., Lincoln, Y.S., Morse, J.M., Pelias, R.J., \& Richardson, L. (2007). Coda: Talking and Thinking about Qualitative Research. In N.K. Denzin \& M.D. Giardina (Eds.), Ethical Futures in Qualitative Research: Decolonizing the Politics of Knowledge (pp. 229-267). Oxford: Berg Publishers.

Denzin, N.K. (1989). Interpretive Interactionism. Newbury Park - London - New Delhi: Sage.

Fleck, L. (2007a). Style myślowe i fakty: Artykuty i świadectwa. S. Werner, C. Zittl, \& F. Schmaltz (Eds.). Warszawa: Wydawnictwo Instytutu Filozofii i Socjologii Polskiej Akademii Nauk.

Fleck, L. (2007b). Nauka a środowisko. In S. Werner, C. Zittl, \& F. Schmaltz (Eds.), Style myślowe i fakty: Artykuty i świadectwa (pp. 264-270). Warszawa: Wydawnictwo Instytutu Filozofii i Socjologii Polskiej Akademii Nauk.

Fleck, L. (1986a). Cognition and Fact: Materials on Ludwik Fleck. R.S. Cohen \& T. Schnelle (Eds.). Series: Boston Studies in the Philosophy of Science, Vol. 87. Dordrecht - Boston - Lancaster - Tokyo: D. Reidel Publishing Company.

Fleck, L. (1986b [1947]). To Look, To See, To Know. In R.S. Cohen \& T. Schnelle (Eds.), Cognition and Fact: Materials on Ludwik Fleck (pp.129-152). Series: Boston Studies in the Philosophy of Science, Vol. 87. Dordrecht - Boston - Lancaster - Tokyo: D. Reidel Publishing Company.

Fleck, L. (1986c [1935]). Scientific Observation and Perception in General. In R.S. Cohen \& T. Schnelle (Eds.), Cognition and Fact: Materials on Ludwik Fleck (pp. 5978). Series: Boston Studies in the Philosophy of Science, Vol. 87. Dordrecht Boston - Lancaster - Tokyo: D. Reidel Publishing Company.

Fleck, L. (1979 [1935]). Genesis and Development of a Scientific Fact. (T.J. Trenn \& R.K. Merton, Eds.; F. Bradley \& T.J. Trenn, Trans.). Chicago - London: University of Chicago Press.

Frank, A.W. (2004). Moral Non-Fiction: Life Writing and Children's Disability. In P.J. Eakin (Ed.), The Ethics of Life Writing (pp. 174-194). Ithaca - London: Cornell University Press.

Frank, A.W. (2002). At the Will of the Body: Reflections on Illness. Boston - New York: Houghton Mifflin Company.

Frank, A.W. (1995). The Wounded Storyteller: Body, Illness, and Ethics. Chicago London: University of Chicago Press.

Frankl, V.E. (1959). Man's Search for Meaning. New York: Washington Square Press.

Garrow, D.J. (2004). Bearing the Cross: Martin Luther King, Jr., and the Southern Christian Leadership Conference. New York: William Morrow \& Company. 
Gornat, T. (2006). "A Chemistry of Stars": Epiphany, Openness and Ambiguity in the Works of James Joyce. Opole: Wydawnictwo Uniwersytetu Opolskiego.

Henry, J. (1965). Pathways to Madness. New York: Random House.

Holman Jones, S. (2004). Building ConnectionsinQualitative Research: Carolyn Ellis and Art Bochner in Conversation with Stacy Holman Jones [113 paragraphs]. Forum Qualitative Sozialforschung/Forum:Qualitative SocialResearch, 5(3), Art.28, http:/ / www.qualitative-research.net/fqs-texte/3-04/04-3-28-e.htm [last accessed: June 15, 2007].

Joyce, J. (1963). Stephen Hero. New York: New Directions Publishing Corporation.

Kafar, M. (2010). O przełomie autoetnograficznym w humanistyce: W stronę nowego paradygmatu. In B. Płonka-Syroka \& M. Skrzypek (Eds.), Doświadczenie choroby w perspektywie badań interdyscyplinarnych (pp. 335-352). Wrocław: Akademia Medyczna im. Piastów Śląskich we Wrocławiu.

Kuhn, T.S. (1996). The Structure of Scientific Revolutions. Chicago - London: University of Chicago Press.

Kuhn, T.S. (1977). The Essential Tension: Selected Studies in Scientific Tradition and Change. Chicago - London: University of Chicago Press.

Langkammer, H. (1990). Słownik biblijny. Katowice: Księgarnia Św. Jacka.

Laozi (2004). Dao De Jing: The Book of the Way. (M. Roberts, Trans.). Berkeley - Los Angeles - London: University of California Press.

Milton, J. (2003 [1667]). Paradise Lost. London: The Folio Society.

Nichols, A. (1987). The Poetics of Epiphany: Nineteenth-Century Origins of the Modern Literary Moment. Tuscaloosa - London: University of Alabama Press.

Pryszmont, J. (1994). Nawrócenie [entry]. In Z. Pawlak (Ed.), Katolicyzm A-Z (pp. 293-294). Poznań: Księgarnia Św. Wojciecha.

Richardson, L. (2001). Getting Personal: Writing-stories. Qualitative Studies in Education, 14, 33-38.

Richardson, L. (1993). Poetic Representation, Ethnographic Presentation and Transgressive Validity: The Case of the Skipped Line. The Sociological Quarterly, 34, 695-710.

Richardson, L. (1977). The Dynamics of Sex and Gender: A Sociological Perspective. Chicago: Rand McNally.

Rorty, R. (1982). Method, Social Science, and Social Hope. In R. Rorty, Consequences of Pragmatism (Essays: 1972-1980) (pp. 191-210). Minneapolis: University of Minnesota Press. 
Skarga, B. (2005). Kwintet metafizyczny. Kraków: Towarzystwo Autorów i Wydawców Prac Naukowych Universitas.

Skarga, B. (2002). Ślad i obecność. Warszawa: Wydawnictwo Naukowe PWN.

Tischner, J. (2005). Świat ludzkiej nadziei. Kraków: Wydawnictwo Znak.

Tischner, J. (2006a). Etyka wartości i nadziei. In J. Tischner (A. Bobko, Ed.), O człowieku: Wybór pism filozoficznych (pp.169-186). Wrocław - Warszawa - Kraków: Zakład Narodowy im. Ossolińskich.

Tischner, J. (2006b). Emmanuel Lévinas. In J. Tischner (A. Bobko, Ed.), O człowieku: Wybór pism filozoficznych (pp. 65-80). Wrocław - Warszawa - Kraków: Zakład Narodowy im. Ossolińskich.

Tischner, J. (2006c). Filozofia dramatu. Kraków: Wydawnictwo Znak.

Tischner, J. (1978). Solidaryzacja i problem ewolucji świadomości. In W. Stróżewski (Ed.), Studia z teorii poznania i filozofii wartości (pp. 91-102). Wrocław: Wydawnictwo Ossolineum.

Tischner, J., \& Kłoczowski, J.A. (2001). Wobec wartości. Poznań: Wydawnictwo Polskiej Prowincji Dominikanów.

Turner, V. (1995). The Ritual Process: Structure and Anti-Structure. New York: Aldine de Gruyter.

Turner, V. (1978). Dramas, Fields, and Metaphors: Symbolic Action in Human Society, Ithaca - London: Cornell University Press.

Wciórka, L. (1994). Transcendencja [entry]. In Z. Pawlak (Ed.), Katolicyzm A-Z (p. 381). Poznań: Księgarnia Św. Wojciecha.

Wielki stownik wyrazów obcych PWN (2010). Warszawa: Wydawnictwo Naukowe PWN.

Woolf, V. (1930). On Being Ill. London: Hogarth Press.

Woolf, V. (1960). To the Lighthouse. London: Hogarth Press. 